\title{
Unpaired female birds use sex to attract already paired males: "La donna è mobile qual piuma al vento"
}

\author{
Role of females in breaking monogamy
}

Pre-existing opinions, assumptions, human hopes and fears were undoubtedly troubled when monogamous birds where first discovered to be unfaithful (GowATY \& KARLIN 1984). Sex is often not exclusive to members of a pair, which shattered the "romantic" picture of several species considered as exclusive mating for their entire life. The "worst" came when we discovered that, in the same way as humans, the birds divorce, cuckold their partner and enjoy a “ménage à trois". After the first papers published on extra-pair paternity in birds (BrAY et al. 1975, McKinney et al. 1983, Alatalo et al. 1984, Gowaty \& KARLin 1984), followed by papers by Westneat (e.g., 1987, 1988) and the discoveries subsequent to the use of the DNA fingerprinting (e.g., Burke 1989, Burke et al. 1989, BirkheAd et al. 1990, WestneAt et al. 1990), by early 1990 there was no remaining scientific debate: it was considered a novelty a socially and genetically monogamous species ... What disillusionment, when we recall that LACK (1968) considered that monogamy was the mating pattern of $90 \%$ of the $>9000$ species of birds! These discoveries naturally spurred scientists on to ask themselves how and why the ultimate variety of social monogamy (the pair bond) is maintained for several breeding seasons. Therefore, as if guided by a fervent spirit of moral rehabilitation, scientists undertook a crusade to try to justify the "bad morality" of some species of birds. At that moment, ecology saved both the behaviourists and the new, bad image of birds. When Davies (1992) stated, under the influence of the Gowaty extension of the Orians model (ORIANs 1969, Gowaty 1981), that "ecological conditions set the stage on which individuals play out their behavioural strategies”, public opinion “drew a sigh of relief”.

Pair bonds are not magical marriages but opportunistic and flexible associations that can potentially end whenever another, better, option arises: pair members may continually test their mate to assess whether it is a good option to remain (BLACK 1996a). To identify whether divorces are accidental or deliberate we need to understand all the possible behavioural, demographic and environmental events that can occur to determine the breaking of the pair bond, as well as the male and female mating strategies and criteria, whether pairing with a new mate improves reproductive potential and which sex is responsible (BLACK 1996a, DhONDT 2002). During the past decade, interest in the female perspective of avian mating system dynamics has been increasing (see review in Cezilly et al. 2000, Dhondt 2002) and the situation partially changed from when GOWATY (1996) underlined that "our theories still cast females as relatively passive creatures, with so little variation in their lives that the underlying constraints on female behaviour have seldom (never!) been systematically explored”. Nevertheless, there could be some aspects of sexual selection that are undefined because of our incomplete knowledge of female sexual behaviour (BERGLund et al. 1993, CunNingham \& BiRKHEAd 1997, Gowaty 1997a, Ligon 1999, Dhondt 2002).

Sex by female floaters: "better option hypothesis"?

The French expression "cherchez la femme" means that females are frequently involved in males' events and lives and that males' behaviour can usually be explained by "looking for the woman". An analysis of sexual selection questions from a "female perspective" added balance and new insights to our existing theoretical frameworks. 
It is well known that males can manipulate females by acting directly on their bodies or indirectly through brokering their access to resources, and that variations in mating patterns are dependent on the females' ability to resist males (GowATy 1992, 1997b). On the other hand, several cases have been recorded of suspected of how females can put pressure on males (EBERHARD 1996, GOWATY 1997a, BIRKHEAD 2000) and there is growing evidence that in many species females control which males obtain extra-pair copulations (EPCs) with them (STUtchbury \& Morton 1995). Moreover, some cases are reported of males whose mate had recently died, adopting an active mating strategy by forcing divorce in a neighbouring territory by aerial chases and fighting during which the female rarely intervened (e.g., KeAR \& STEEL 1971; EldRIDGE 1985, 1986). But what about females? The information about a more active female choice is more frequently related to females moving from their territory to consort with a lone territorial male (e.g., Gibson \& LAngen 1996, Williams \& Mckinney 1996). The question is whether such females are always "innocent victims" of male pressures or they occupy a vacant territory only when the resident male is a lone one.

We wonder whether, in the natural scenario of a widowed or floater female seeking a mate, she could try to attract an already paired male with the purpose of producing a divorce (e.g., better option hypothesis; Ens et al. 1993), later moving the male to a new territory or trying to chase away the resident female. This is an "exciting" possibility because, at last, females would not only be, as too often frequently reported (see GowATY 1997a), the object of "forced copulations" or "virgins"/widows waiting for the mate of their life, but creatures enthusiastically seeking copulations (e.g., PETRIE 1992) and thus facilitating the "work" of males to obtain sex.

The main problem in the detection of mating processes is the difficulty of direct observations of individual behaviours (RAMSAY et al. 2000) and the need for marked or radioequipped birds. Otherwise, we can only detect that a change has occurred in a pair and observe the consequences. We cannot say how it happened and it is hard to deduce the process from knowledge of the pattern only.

\section{EPCs hypothesis does not explain the behaviour of female eagles}

During a long-term study of the Spanish Imperial Eagle (Aquila adalberti) in Doñana (south-western Spain; FERRER 2001), 60\% of breeders and floaters were marked and equipped with radios. Over the period of the study, it was possible to observe four sub-adult females repeatedly visiting the territory of already paired males. Three were floaters: they repeatedly stimulated the paired males and copulated with them in their territories. For the fourth female, already established in a territory as a lone resident, repeated visits to a male territory were recorded but not copulations, although we cannot exclude the possibility that they occurred when specific observations were not in progress. In any case, these females never acquired the mate with whom they copulated became the males continued with their early partners.

To our knowledge, in the other reported cases of females visiting already paired males (e.g., Smiseth \& Amundsen 1996, Neudorf et al. 1997, Double \& Cockburn 2000) the scenario was always different from that seen in our eagles. For example, in the Great Tit Parus major, several females were observed flying towards singing males (or places of conflict between two males) to start foraging close by (DHONDT et al. 1996). In Blue Tits (Parus caeruleus), Hooded Warblers (Wilsonia citrina), Indigo Buntings (Passerina cyanea), Pied Flycatchers (Ficedula hypoleuca) and Tree Swallows (Tachycineta bicolor), several females visited a neighbouring already mated male, solicited there, mated and returned to their nesting territory (DALE et al. 1992, Kempenaers et al. 1992, Venier et al. 1993, Black 1996b, Neudorf et al. 1997). In the Sparrowhawk (Accipiter nisus), the observed EPCs were apparently initiated by females visiting the nesting places of other males (NEWTON \& WYLLIE 1996).

The main difference between all these observations and the reported observation of the Spanish Imperial Eagle is that they referred to already paired females cuckolding their males because of low genetic quality or to assess and form alliances with a possible future partner (WAgner 1992, Otter \& RAtCliffe 1996, Ramsay et al. 2000). On the other hand, in these situa- 
tions, the males accepting EPCs probably had the advantage of producing extra offspring without commitment (NEWTON \& WYLLIE 1996). The copulations stimulated by the female eagles do not fall into the classical EPC patterns (KEMPEnAERs et al. 1992, VENIER et al. 1993, BIRKHEAD 1998) simply because the females were not mated. A possible explanation of this behaviour is that females showed their willingness to copulate in an active attempt to attract a new mate by provoking a divorce. This particular behaviour could also derive from the typical behaviour of birds of prey, forced to spend a lot of time away from the nest site during hunting. When a mate is spending time away from the other, a solitary female could try to approach the male to solicit copulation and establish a new pair bond. Such behaviour could be driven by the female's need for a territory-holding male, as also pointed out by Ligon (1999). Moreover, a positive relationship between divorce and EPCs was found by Cezilly \& NAger (1995), concluding that the better option hypothesis best accounts for this relationship. In this case, too, this kind of behaviour relies on intrasexual competition for high-quality males holding good territories (CEZILly \& NAGER 1995). Although our observations only concern four females, we considered this information important because female birds of prey repeatedly visiting a territory of a paired male and copulating with the owner are difficult to detect, and it could be a more generalized behaviour in several species and scenarios. For example, Walls \& KenWARD (1998) and FERRER (2001) reported several cases of floaters (of Buzzards Buteo buteo and Spanish Imperial Eagles, respectively) visiting occupied territories and living at their borders.

To our knowledge, the attraction of a paired male of a monogamous, territorial and long-lived species by a lone female accepting copulations has never been detected or proposed as a possible mechanism of divorce. Moreover, in such species, it is generally reported that males take the initiative, making frequent excursions into neighbouring territories both before and during the breeding season, and the female's response to this display of EPCs then determines whether the process continues (BLACK 1996b, RUSSEL \& ROWLEY 1996).

Because a divorce as a consequence of these copulations was never observed (probably due to small sample size), we wonder if there is an explanation of this behaviour other than mate acquisition. In a free world where there is space for reverse and homosexual mounting, are we able to discard the idea of non-adult birds having sex only to improve their sexual ability or simply to appease their sexual instinct due to the high level of reproductive hormones (WINGFIELD \& FARNER 1993)?

\section{Acknowledgements}

We thank L. Beani, M.G. Forero, W. Forstmeier, P. Gowaty, M. Lambrechts and F. Sergio for their useful critiques of the first version of the manuscript. V. Penteriani has been supported by a Marie Curie Fellowship of the European Community programme "Improving the Human Research Potential and the Socio-Economic Knowledge Base” under contract number HPMF-CT-2000-01098. The authors is solely responsible for information communicated and the European Commission is not responsible for any view or resulted expressed.

\section{References}

Alatalo R.V., Gustafsson L. \& Lundberg A. 1984. High frequency of cuckoldry in pied and collared flycatchers. Oikos 42: 41-47.

Berglund A., Magnhagen C., Bisazza A., Konig B. \& Huntingford F. 1993. Female-female competition over reproduction. Behavioral Ecology 4: 184-187.

BIRKHEAD T.R. 1998. Sperm competition in birds: mechanisms and functions, pp. 579-622. In: Birkhead T.R. \& Møller A.P., Edits. Sperm competition and sexual selection. San Diego: Academic Press.

Birkhead T.R. 2000. Promiscuity. An evolutionary history of sperm competition and sexual conflict. London: Faber and Faber. 
Birkhead T.R., Burke T., Zann R., Hunter F.M. \& Krupa A.P. 1990. Extra-pair paternity and intraspecific brood parasitism in wild zebra finches Taeniopygia guttata, as revealed by DNA fingerprinting. Behavioral Ecology and Sociobiology 27: 315-324.

Black J.M. 1996a. Introduction: pair bonds and partnership, pp. 3-20. In Black J.M., Edit. Partnership in birds. Oxford: Oxford University Press.

Black J.M. 1996b. Partnership in birds. Oxford: Oxford University Press.

Bray O.E., Kennelly J.B. \& Guarino J.L. 1975. Fertility of eggs produced on territories of vasectomized red-winged blackbirds. Wilson Bulletin 87: 187-195.

Burke T. 1989. DNA fingerprinting and other methods for the study of mating success. Trends in Ecology \& Evolution 4: 139-144.

Burke T., Davies N.B., Bruford M.W. \& Hatchwell B.J. 1989. Parental care and mating behaviour of polyandrous dunnocks Prunella modularis related to paternity by DNA fingerprinting. Nature 338: 249-251.

Cezilly F. \& Nager R.G. 1995. Comparative evidence for a positive association between divorce and extra-pair paternity in birds. Proceedings of the Royal Society of London (B) 262: 7-12.

Cezilly F., Préault M., Dubois F., Faivre B. \& Patris B. 2000. Pair-bonding in birds and the active role of females: a critical review of the empirical evidence. Behavioural Processes 51: 83-92.

Cunningham E. \& Birkhead T. 1997. Female roles in perspective. Trends in Ecology \& Evolution 12: 337-338.

Dale S., Rinden H. \& Slagsvold T. 1992. Competition for a male restricts mate search of female pied flycatchers. Behavioral Ecology and Sociobiology 30: 165-176.

Davies N.B. 1992. Dunnock behaviour and social evolution. Oxford: Oxford University Press.

Dhondt A.A. 2002. Changing mates. Trends in Ecology \& Evolution 17: 55-56.

Dhondt A.A., Adriaensen F. \& Plompen W. 1996. Between- and within-population variation in mate fidelity in the Great Tit, pp. 235-248. In: Black J.M., Edit. Partnership in birds. Oxford: Oxford University Press.

Double M. \& Cockburn A. 2000. Pre-dawn infidelity: females control extra-pair mating in superb fairy-wrens. Proceedings of the Royal Society of London (B) 267: 465-470.

EBerhard W.G. 1996. Female control: sexual selection by cryptic female choice. Princeton: Princeton University Press.

ELdRIDGE J.L. 1985. Display inventory of the Blue Duck. Wildfowl 36: 109-121.

EldRIDGE J.L. 1986. Territoriality in a river specialist: the Blue Duck. Wildfowl 37: 123-135.

ENS B.J., SAfriel U.N. \& HARRIS M.P. 1993. Divorce in the long-lived and monogamous oystercatcher, Haematopus ostralegus: incompatibility or choosing the better option? Animal Behaviour 45: 1199-1217.

FERrer M. 2001. The Spanish Imperial Eagle. Barcelona: Lynx Edicions.

Gibson R.M. \& LANGEN T.A. 1996. How do animals choose their mates? Trends in Ecology \& Evolution 11: 468-470.

Gowaty P.A. 1981. An extension of the Orians-Verner-Willson model to account for mating systems besides polygyny. The American Naturalist 118: 851-859.

Gowaty P.A. 1992. Evolutionary biology and feminism. Human Nature 3: 217-249.

GowATY P.A. 1996. Battles of the sexes and origins of monogamy, pp. 21-52. In: Black J.M., Edit. Partnership in birds. Oxford: Oxford University Press.

Gowaty P.A. 1997a. Principles of females' perspectives in avian behavioural ecology. Journal of Avian Biology 28: 95-102.

Gowaty P.A. 1997b. Feminism and evolutionary biology. Dordrecht: Kluwer Academic Publisher.

Gowaty P.A. \& KARLin A.A. 1984. Multiple maternity and paternity in single broods of apparently monogamous eastern bluebirds (Sialia sialis). Behavioral Ecology and Sociobiology 15: 91-95.

Kear J. \& SteEl T.H. 1971. Aspects of social behaviour in the Blue Duck. Notornis 18: 187198. 
Kempenaers B., Verheyen G.R., Van Den Broeck M., Burke T., Van Broeckhoven C. \& Dhond A.A. 1992. Extra-pair paternity results from female preference for high-quality males in the blue tit. Nature 357: 494-496.

LACK D. 1968. Ecological adaptations for breeding in birds. London: Chapman and Hall. LIGON

J.D. 1999. The evolution of avian breeding systems. Oxford: Oxford University Press. McKINNEY

F., DeRrickson S.R. \& MineAu P. 1983. Forced copulation in waterfowl. Behaviour 86: $250-294$.

Neudorf D.L., Stutchbury B.J.M. \& Piper W.H. 1997. Covert extraterritorial behavior of female hooded warblers. Behavioral Ecology 8: 595-600.

Newton I. \& Wyllie I. 1996. Monogamy in the Sparrowhawk, pp. 249-267. In: Black J.M., Edit. Partnership in birds. Oxford: Oxford University Press.

Orians G.H. 1969. On the evolution of mating systems in birds and mammals. The American Naturalist 103: 589-603.

OtTER K. \& RAtcliffe L. 1996. Female initiated divorce in a monogamous songbird: abandoning mates for males of higher quality. Proceedings of the Royal Society of London (B) 263: 351-355.

Petrie M. 1992. Copulation frequency in birds: Why do females copulate more than once with the same male? Animal Behaviour 44: 790-792.

Ramsay S.M., Otter K.A., Mennill D.J., Ratcliffe L.M. \& Boag P.T. 2000. Divorce and extrapair mating in female black-capped chickadees (Parus atricapillus): separate strategies with a common target. Behavioral Ecology and Sociobiology 49: 18-23.

Russel E. \& Rowley I. 1996. Partnerships in promiscuous Splendid Fairy-wrens, pp. 162-173. In Black J.M., Edit. Partnership in birds. Oxford: Oxford University Press.

Smiseth P.T. \& Amundsen T. 1996. Female bluethroats (Luscinia s. svecica) regularly visit territories of extrapair males before egg laying. The Auk 112: 1049-1053.

Stutchbury B.J.M. \& Morton E.S. 1995. The effect of breeding synchrony on extra-pair mating systems in songbirds. Behaviour 132: 675-690.

Venier L.A., Dunn P.O., Lifjeld J.T. \& Robertson R.J. 1993. Behavioural patterns of extrapair copulation in tree swallows. Animal Behaviour 45: 412-415.

WAGNER R.H. 1992. The pursuit of extra-pair copulations by monogamous female razorbills: how do females benefit? Behavioral Ecology and Sociobiology 29: 455-464.

WALLS S.S. \& KENWARD R.E. 1998. Movements of radio-tagged buzzards Buteo buteo in early life. Ibis 140: 561-568.

WestneAt D.F. 1987. Extra-pair fertilizations in a predominantly monogamous bird: genetic evidence. Animal Behaviour 35: 877-886.

Westneat D.F. 1988. Male parental care and extrapair copulations in the indigo bunting. The Auk 105: 149-160.

Westneat D.F., Sherman P.W. \& Morton M.L. 1990. The ecology and evolution of extra-pair copulations in birds. Current Ornithology 7: 331-369.

Williams M. \& MCKinney F. 1996. Long-term monogamy in a river specialist - the Blue Duck, pp. 73-90. In: Black J.M., Edit. Partnership in birds. Oxford: Oxford University Press.

WingField J.C. \& FARNER D.S. 1993. Endocrinology of reproduction in wild species. Avian Biology 9: 162-327.

\section{Penteriani ${ }^{1}$ and M. Ferrer}

Department of Applied Biology, Estación Biológica de Doñana (EBD), Consejo Superior de Investigaciones Científicas, Avda. de María Luisa s/n, Pabellón del Perú, Apdo. 1056, 41013 Seville, Spain

${ }^{1}$ Corresponding author: Vincenzo Penteriani (Phone: + 349542348 44; Fax: + 3495 46211 25; E-mail: penteriani@ebd.csic.es). 